\title{
The Development of Integrated Thematic Textbooks with Scientific Approach for Elementary Schools Students
}

\author{
Winda Elvita ${ }^{1}$, Risda Amini ${ }^{2}$, Riska Ahmad $^{3}$ \\ ${ }^{123}$ Universitas Negeri Padang
}

Article Info:

Accepted : October 2019

Published Online: November 2019

\begin{abstract}
The preliminary survey in Elementary School in Lima Puluh Kota District showed that the textbook for thematic learning was not in accordance with the principles of integrated learning and not yet in accordance with the around environment of the students, so that the lesson was not understood of the students. therefore the purpose of this study is to develop integrated thematic textbooks using the scientific approach valid, practical and effective.The research used the four D model of Tiagahajan that consist of 4 stages, namely: define, design, develop, and disseminate. The research instruments were observation sheets, validation sheets, questionnaires, learning outcomes tests. The results showed that integrated thematic textbooks with a scientific approach include valid categories based on expert judgment. Textbooks include very practical categories based on teacher and student responses. Effectiveness of textbooks based on student learning activities and mastery learning. The most of students were active in learning. The student learning outcome in the knowledge, skills, and attitudes domain has been include the mastery learning category for the most of students (more than 85\%). Thus it can be concluded that integrated thematic textbooks with scientific approaches were feasibility of being used as reference books in Elementary School.
\end{abstract}

Keywords: Integrated, scientific approach, textbooks

\section{INTRODUCTION}

Integrated thematic learning is one approach in integrated learning that enables students, both individually and in groups, to actively explore and discover scientific concepts and principles holistically, meaningfully and authentically (R Amini \& Helsa, 2018; Rusman). The use of integrated thematic learning in Elementary School / Madrasah Ibtidaiyah leads to improving the quality of education and providing a very supportive prospect for the implementation of the 2006 curriculum and the 2013 curriculum which is competency based.The application of integrated thematic learning in elementary schools has implications for the availability of textbooks, especially books that are adequate and can meet the learning needs that are integrated between the content of one subject with other subjects, even with real life students (Risda Amini, 2019; Gupta \& Belford, 2019).

Thematic learning is basically a combination of various disciplines that are covered in natural sciences, so thematic learning requires a more complete textbook and comprehensive compared to non thematic learning (Fitriani, Djamas, \& Fauzi, 2019). In one learning topic, a number of learning resources are needed in accordance with the number of competency standards which are the number of study fields included in it.

Based on the teaching experience in the lower class and the results of observations at SD N 02 Koto Tuo in Harau Subdistrict, Lima Puluh Kota, in class III, data was obtained that the learning had not fully used integrated thematic learning, the learning carried out by teachers was still expository, namely teachers lecturing and stuffing students with material verbally symbols, another problem found is the use of learning textbooks that are still separate based on subjects. Integrated thematic textbooks are still difficult to find in the field for the 2006 curriculum, although they are available, but they are not in accordance with the learning objectives (Risda Amini, 2017; Gupta \& Belford, 2019). 
The implementation of learning that has not used integrated thematic learning models, the use of inappropriate approaches and the use of learning textbooks that are still separate causes low involvement of students in learning activities, knowledge received by students is not holistic, and lacks direct experience to students, so the results learners become low (Gupta \& Belford, 2019; Kadir, 2013).

The importance of implementing integrated thematic learning, the use of appropriate learning approaches and the use of thematic textbooks in elementary schools is reinforced by research conducted by Wahyuni entitled the influence of the use of integrated thematic learning models on learning achievement, this study shows that the use of integrated thematic models of achievement learning to get an average score of 65.92 compared to learning achievement with a non thematic learning model which is 50.59. Likewise the data obtained from the Ministry of National Education (Sari \& Syamsi, 2015) that the number of repeat and drop out students of low class compared to the high class of 1999/2000 had a significant comparison. The repeat number for class I-III is $18.24 \%$ while class IV-VI is $8.11 \%$. As a result of the high number of repeats in the low class is influenced by the learning model used by teachers in the form of non thematic learning. Students have not been able to understand the material presented separately (Andi, 2014).

\section{METHOD}

This type of research is development research that aims to develop teaching materials that are valid, practical, and effective. States that the method of research and development is research that aims to produce certain products and test the effectiveness of these products (Sugiyono, 2007). The aim of development research in education is not to formulate or test theories but to develop effective products that will be used in schools.

Development research begins by looking at the problems that arise in the learning process in schools, then think of an effort to overcome the problem in the form of an effort to develop a learning product that is expected to help teachers and students. The resulting product is validated in advance by experts using an expert validation questionnaire. In addition, it is also necessary to know the practicality and effectiveness of the products developed so that they can be revised to truly be used (Fitriani, et al., 2019). The development model used was a 4-D model, a 4-D model emerged in 1974 developed by S. Thiagarajan, Dorothy S. Semmel, and Melvyn I. Semmel. According to Thiagarajan, et al (Usmeldi, 2016) this model consists of four stages, namely defining, designing, developing and disseminating.

This 4-D development model was chosen because (1) it is more appropriate to be used as the basis for developing textbooks, (2) systematic, (3) its development involves the assessment of experts so that before the field trials have been carried out revisions based on assessment, suggestions, and input from experts. The study began in October 2016 until August 2017 in 02 Koto Tuo Public Elementary School, Harau Sub-District, Lima Puluh Kota Regency. The subjects tried in this research and development are as follows: a trial was conducted on class III students of SD Negeri 02 Koto Tuo in Harau Subdistrict as many as 21 Students and the distribution was carried out on 02 Tarantang Elementary School students in Harau District, Lima Puluh Kota District with the number of students 18 people.

This lesson textbook was developed using the four D (4-D) model, namely (1) define, at the defining stage there are three steps taken, namely: curriculum analysis (KTSP), concept analysis, student analysis. (2) design (design), the design phase aims to design teaching books. There are three phases of activity at this stage: compiling benchmark reference tests, media selection, format selection. (3) developing stages to produce products that are carried out through two steps, namely: expert assessment followed by revision and trial development. The purpose of this stage is to produce student textbooks that are valid, practical and effective. (4) disseminate this stage to promote development products so that they are accepted by users, whether individuals, groups, or systems.

Instrument is one tool for data collection. The means of collecting data in this development research is a questionnaire (questionnaire). Questionnaires (questionnaires) are used to obtain data on the validity, effectiveness and practicality of textbooks. Research instruments developed for data collection in this study are validation instruments, practicality instruments (teacher response questionnaires, students, interview guides) and effectiveness instruments (observation sheet student activity and learning outcomes). The analysis technique used in the study is descriptive data analysis, which describes the validity of teaching books, the practicality of textbooks, and student competencies that show the effectiveness of textbooks. 
The analysis technique used in this study is descriptive data analysis, which describes the validity of teaching books, practicality of textbooks, and student competencies that show the effectiveness of teaching books. As for the criteria for feasibility textbooks by experts include the feasibility of content, language, presentation, and graphics. Practical analysis techniques are used for data analysis of observations of the implementation of lesson plans, student response questionnaires, teacher responses and interview guidelines. While the techniques for analyzing the effectiveness of textbooks are taken from data on the results of filling out student learning activities sheets and analysis of student learning outcomes consisting of learning outcomes aspects of knowledge, attitudes, and skills. In this research, the feasibility of integrated thematic textbooks using the scientific approach in the lower classes was determined as valid. So if the results of the research of each aspect are valid, then this development product is considered appropriate for use.

\section{RESULT AND DISCUSSION}

The results of this development in the form of integrated thematic textbooks using the scientific approach to the low class. The textbook developed is a book for students. Student books are used as a guide to learning activities to facilitate students in mastering certain competencies and are used to carry out activities in the learning process. Based on this, the student book developed can facilitate teachers and students in the learning process. These things are in line with the opinion of Dick, Carey, \& Carey (Usmeldi, 2016) which states that textbooks should contain written content and material that can facilitate teachers and students to achieve learning goals. The student book developed refers to the preparation of textbooks according to the Ministry of National Education which consists of: (1) cover, (2) preface, (3) table of contents, (4) usage instructions, (5) graduate competency standards and core competencies, (6) the title of the sub-theme and mapping of basic competencies, (7) learning themes, learning indicators and objectives, (8) integrated thematic learning steps in textbooks, (9) evaluation, (10) assessment, (11) bibliography. The textbook developed is in the form of A4 with different font sizes ranging in size, 11,12,14,16, 20 and 24. While the letters used are Times New Romancomic Sans MS, Cambria, Berlin sans FB, and Calibri.

After the initial product of the integrated integrated textbook for the low class was completed, the researcher conducted product validation on three expert validators from the university. In this activity, experts were asked to assess the textbooks that had been made. Assessment includes content, presentation, language and graphics. The validation process is done by filling in the validation questionnaire sheet. Validation questionnaires are filled in by each validator, based on their respective expertise. The validator is asked to provide an assessment and suggestions for improvements to the textbooks that have been designed. Suggestions provided by the validator serve as feedback to researchers to revise the textbooks produced. Table 1 . Results of Questionnaire Analysis of Validation of Integrated Thematic Textbooks with a Scientific Approach to Low Classes.

Tabel 1. Product Test Results

\begin{tabular}{lcl}
\hline Assessment Aspect & Validity value & Category \\
Content qualification & 85,71 & Very valid \\
& & \\
Linguistic qualification & 87,50 & Very valid \\
resentation feasibility & 87,50 & Very valid \\
The fitness eligibility & 89,28 & Very valid \\
\hline
\end{tabular}

After the teaching book is declared valid, the next step is to conduct a trial to find out the practicality and effectiveness of the textbooks developed. The trial was conducted on class III A SDN 02 Koto Tuo Harau SubDistrict, Lima Puluh Kota Regency. The trial was conducted for 3 meetings on the theme of hobbies.

The practicality of the textbooks developed can be seen from the observation sheet of the implementation of learning, the results of practical questionnaire analysis by teachers and students, observation of the use of textbooks by students and analysis of interviews. The learning implementation observation data was taken from the observation sheet of the RPP implementation obtained by the observer at each meeting. For more details, can be seen in table 2 . 
Table 2. Results of Observation on the Implementation of RPP

\begin{tabular}{ccccc} 
Learning & \multicolumn{2}{c}{ Observer Assessment Percentage } & Total Average & Category \\
& $\mathrm{O} 1$ & $\mathrm{O} 2$ & & \\
learning 1 & 3.3 & 3.4 & 3.35 & practical \\
learning 2 & 3.6 & 3.7 & 3.65 & practical \\
learning 3 & 3.9 & 3.9 & 3.9 & practical \\
\multicolumn{2}{c}{ Practical Level of Implementation of RPP } & 3.63 & practical
\end{tabular}

The teacher response questionnaire is given to find out the teacher's opinion on the textbooks that have been compiled. Analysis of data obtained from each teacher's questionnaire response to the practicality of textbooks can be seen in table 3 below.

Table 3. Results of Teacher Response Questionnaire Analysis

\begin{tabular}{lll}
\hline The Results & Average & Category \\
& & \\
Teacher 1 & 91,66 & Very practical \\
Teacher 2 & 86.11 & Very practical \\
\hline
\end{tabular}

For student response questionnaires given to students to find out students' opinions about the practicality of textbooks. The student response questionnaire was filled by 23 students of SD N 02 Koto Tuo at the end of the trial. In summary the results of the practical sheet on student response questionnaires after using lesson text books can be seen in table 4 below.

Table 4. Results of Practicality Questionnaire for Students

\begin{tabular}{llll}
\hline The Results & Total & Average & Category \\
Student response form & 909,76 & 82,71 & Very practical \\
\hline
\end{tabular}

Student activities during the learning activities take place are observed by using student activity observation instruments. Average observations of student activities Can be seen in table 5 below.

Table 5. Average Observation Results of Student Activities During Trial and Distribution

\begin{tabular}{lll}
\hline The Results & Average & Category \\
trials & 81,39 & Very practical \\
Distribution & 82,59 & Very practical \\
\hline
\end{tabular}

Another component that is used to determine the effectiveness of the textbooks developed is by assessing student learning outcomes that are assessed from the aspects of attitudes, skills and knowledge of students. This assessment is then analyzed to obtain a mean score. These results will be compared with the school KKM. The results of the assessment data during the learning process can be seen in table 6 below.

Table 6. Average Student Learning Outcomes in Trials and Spreads

\begin{tabular}{lllll}
\hline The Results & Knowledge & Attitude & Skills & ategory \\
Trials & 90,14 & 83.65 & 82.56 & ery good \\
spread & 85,18 & 86,25 & 85.95 & ery good \\
\hline
\end{tabular}


Based on table 6, student learning outcomes from 3 aspects obtain a very good category. This indicates that the textbooks developed are effectively used.

\section{COUNCLUSION}

Based on the development, testing, and dissemination carried out, the researcher can conclude a number of things, as follows:Integrated thematic textbooks using the scientific approach produced in this development study are very valid in terms of contents, namely 85.71 linguistic aspects $87.50,87.50$ and 89.28 aspects of presentation. Integrated thematic textbooks using the scientific approach produced in this development research can be stated to be very practical from the results of the teacher response analysis which is an average of 88.89 and the response aspects of students with an average of 82.71Integrated thematic textbooks using a characterbased scientific approach produced in this development research have been declared effective in terms of activities and learning outcomes. Student activities can be seen from the results of student observations at the time of the trial with an average of 81.39 when the spread becomes 82.59 which is in the very active category. Student learning outcomes consist of 3 aspects, namely attitudes, knowledge and skills. On the attitude aspect when the trial is obtained the overall average is 83.65 and when the spread becomes 86.25 it is in the already entrenched category. On the knowledge aspect when the trial is obtained, the completeness percentage is 90.00 and when the spread is 85.00. On the skill aspect during the trial it was obtained an average of 82.56 and when the spread of 85.95 was in the good category.

\section{REFERENCES}

Amini, R. (2017). The Development Of Integrated Learning Based Students'book To Improve Elementary School Students'competence. Unnes Science Education Journal, 6(2).

Amini, R. (2019). The Effect of Integrated Model and Motivation Models on Learning Outcome of Students in Animal and Human Organ Order Material at Class V Elementary School/Paket A Program. Paper presented at the 1st Non Formal Education International Conference (NFEIC 2018).

Amini, R., \& Helsa, Y. (2018). Integrated model in science for elementary school. Paper presented at the Journal of Physics: Conference Series.

Andi, P. (2014). Pengembangan Bahan Ajar Tematik Tinjauan Teoritis dan Praktis. Jakarta: Kencana Prenadamedia Group.

Fitriani, H., Djamas, D., \& Fauzi, A. (2019). Textbook design of integrated science subject with integrated model in bio magnetic topic. Paper presented at the Journal of Physics: Conference Series.

Gupta, T., \& Belford, R. (2019). Conclusion: Technology Integration in Chemistry Education and Research: What Did We Learn and What Can We Expect Going Forward? Technology Integration in Chemistry Education and Research (TICER) (pp. 281-301): ACS Publications.

Kadir, A. (2013). Konsep pembelajaran kontekstual di sekolah. Dinamika ilmu, 13(1).

Rusman, D. M.(2015). Pembelajaran Tematik Terpadu. Jakarta: Raja Grafindo Persada.

Sari, I. P., \& Syamsi, K. (2015). Pengembangan buku pelajaran tematik-integratif berbasis nilai karakter disiplin dan tanggung jawab di sekolah dasar. Jurnal Prima Edukasia, 3(1), 73-83.

Sugiyono, M. P. P. (2007). Pendekatan Kuantitatif. Kualitatif, dan R\&D, Bandung: Alfabeta.

Usmeldi, U. (2016). The Development of Research-based Physics Learning Model with Scientific Approach to Develop Students' Scientific Processing Skill. Jurnal Pendidikan IPA Indonesia, 5(1), 134-139. 